\title{
Serving time with a sea view: The prison cell and healthy blue space
}

Jennifer Turner, Dominique Moran and Yvonne Jewkes

\section{Introduction}

At 9am on 13 August 2016, 800 competitors in the $24^{\text {th }}$ annual Alcatraz Sharkfest Swim were dropped just off the rocks of the island housing Alcatraz Federal Prison in San Francisco Bay and challenged to swim 1.5 miles back to the city shore (Terry 2016). This and other challenges taking place since the closure of the prison, derive playfulness from the altogether more serious history of its geographical location on an island surrounded by deep, cold waters with strong undercurrents. Its nickname, the Rock, is apt, since topographically the island is a drowned mountain, with only a thin strip of dirt that supports little flora and fauna (Jarvis 2004). Some of the United States' most notorious prisoners were incarcerated here from 1934 to 1963 under the premise that Alcatraz's watery surroundings would make the prison impossible to escape from, although there were in fact 14 documented escape attempts involving 34 prisoners: 23 were recaptured, six were shot and killed, but five remained unaccounted for. The authorities insisted they must have drowned (Jarvis 2004). In addition, prison folklore held that the waters surrounding Alcatraz were shark-infested. Tales were told of a shark named 'Bruce', said to have been raised with only one fin by the Bureau of Prisons in order that it would swim continually around the island waiting for its prey (Babyak 2001).

The significance of the surrounding water for the prisoners themselves is not something that features prominently in the performance of the site as a destination for penal tourism ${ }^{1}$. Curators have paid attention to the value of the sea in aiding air circulation around the crowded cell-block and commented on the chill brought by inclement weather. However, the view - 
which may be taken from most windows in the building - features less in the narrative of the prison's history. The impacts that a sea view might have had on prisoners are difficult to garner from the prison's archives, but it seems likely that the cold and dangerous waters surrounding Alcatraz could only have exacerbated the pains of imprisonment experienced by its inmates. But can a waterscape have positive effects in a carceral setting? Combining perspectives from sociology, therapeutic and carceral geographies, and criminological studies of the prison, our aim in this chapter is to explore prisoners' rational and visceral responses to a sea view and to discuss the value in interrogating 'healthy blue space' (Foley and Kistemann 2015) under contingent circumstances where individuals cannot choose to accept or reject interaction with their environs, and where the very nature of enforced residence can have negative effects on mental health (Jordan 2011).

The notion of 'healthy prisons' is now well established in policy; for example, Her Majesty's Inspectorate of Prisons () (2014) employs 'healthy prison tests' as standards against which all prisons in England and Wales are independently inspected. However, the Inspectorate's focus remains on what is 'just' and 'decent', rather than what is 'healthy' in a medical or therapeutic sense. Our aim, in short, is to explore the value of Foley and Kistemann's conceptualisation of 'healthy blue space' and to respond to their call to 'extend the scope spatially, methodologically and in inter-disciplinary ways as part of a broader hydro-social set of therapeutic geographies' (2015: 157). Using empirical data gathered from prisoners and prison staff at a prison located on a seashore in the UK, and drawing on notions of therapeutic landscapes, the chapter theorises the prison cell with a sea view as a potentially nurturing rather than punitive environment; one that might heal rather than inflict further harm. After summarising the expansion of inter-disciplinary therapeutic landscape studies from 'green' to 
'blue' spaces, we note that the prison disrupts conventional understandings of therapeutic landscapes, as water sometimes engenders negative associations in the carceral environment associations of punishment and control, rather than the beneficial experiences commonly emphasised; and contend that much existing literature focuses on the health-enabling or therapeutic capacity of blue space via bodily immersion. Although previous research highlights the value of a sea view, for instance, it is the view in conjunction with an ability to physically engage with the water that is usually argued to have health benefits. Using interview and focus group data generated from staff and prisoners in a recently-built coastal prison in the UK, we will suggest a more complex relationship with blue space; that is, the highly limited, yet powerful visual and sensory interaction that prisoners unable to 'jump in' to the watery landscapes around them (Foley 2015: 219) may nonetheless have - a relationship that complicates individual attachments to the space of their prison cell and traditional understandings of the cell as a 'constant', 'static' space. We conclude by suggesting possibilities for development of theorisations of therapeutic blue space and discussing the benefits that may be generated by a reconsideration of prison location and exterior view outlook.

\section{Healthy blue space and the carceral landscape}

The concept of therapeutic landscapes was introduced by Gesler (1992) and has subsequently been explored within studies of environment, health and care (Airey 2003; Gesler 1996, 1998, Kearns and Barnett 1999; Kearns and Gesler 1998; Palka 1999; Williams 1998, 1999). Velarde et al. described the main health benefits of exposure to landscapes as being 'reduced stress, improved attention capacity, facilitating recovery from illness, ameliorating physical well-being in elderly people, and behavioural changes that improve mood and general well-being' (2007: 
210). The recognition of landscape as a 'key element of individual and social wellbeing' (Foley and Kistemann 2015: 159) has led to policy-level changes concerned with the protection, management and planning of these environments. But while traditional landscape studies have focussed on 'green' space, recent studies have explored the impact of 'blue' vistas (Anderson and Peters 2014; Strang 2004). For example, Luttik's (2000) Netherlands-based study found that houses with views of water cost between 8 and 12 per cent more than those without, while Lange and Schaeffer (2001) reported guests' willingness to pay 10 per cent more for 'lake view' rooms, rather than rooms with forest views in hotels in Switzerland. However, the desire for these rooms may be more than just personal preference. In 2015, Foley and Kistemann coined the term 'healthy blue space,2 after collating a wealth of documentation about the value of blue spaces including both coastal areas (Depledge and Bird 2009; Wheeler et al. 2012; White et al. 2010) and inland waters known as 'urban blue' (Völker and Kistemann 2011) for health and wellbeing. In addition to evidence concerning the benefits of views of water, bodily immersion in water has long been considered therapeutic, as witnessed in the development of Victorian spas in seaside towns; lidos, which had become a national institution in the UK by the 1930s; and in the contemporary vogue for outdoor- and open-water swimming (Corbin 1994; Deakin 2000; Parr 2011; Shields 2013). In 2009, Natural England reported that, in the UK, there were nearly 250 million visits to the coast and 180 million to other aquatic environments including rivers, canals and lakes. Aside from the therapeutic benefits of exercise and hydro-immersion, these watery locations 'have wide cultural and emotional resonance' through the health-enabling advantages that derive from the blue components of the water and sky (Foley 2015: 218) . $^{3}$

Although blue space literatures conventionally refer to access to and views of bodies of water - which of course frequently appear in shades of grey or green rather than actually blue- 
the sky is another 'blue' space: access to sight of which is considered therapeutic in a number of ways. Sky views usually coexist with natural light (and dark), which help regulate circadian rhythms and thereby promote wellbeing. 'Sky View Factor' (Oke 1981), a measure defining the fraction of sky visible from a given position on the ground, is used in landscape assessment, and views of the sky, the horizon, slow-moving clouds, sunsets and so on are frequently considered part of therapeutic landscapes (e.g. Lengen 2005). At the horizon where land or water and sky meet, there is a sense of depth which is recognised as 'a primary feature of landscape' (Casey 2001). This enables a sense of reality in space - occlusion of distant objects by closer objects, perspective, shading, motion parallax (Sacks 2010), and an essential sense of reality (Lengen 2005), a sense of belonging, and a sense of being (Sacks 2010) - or 'Dasein' (Heidegger 1927). These intangible yet existential effects of viewing landscapes are reflected in recent studies of therapeutic landscapes, which point out that place is experienced differently by different individuals and therefore may deliver different therapeutic outcomes (Conradson 2005). In other words, and in line with geographical understandings of relational space, environments cannot be fully appraised objectively, but instead must be understood relationally.

So what is the relevance of this discussion to the prison; and in particular the prison cell? Prison spaces are also relational. They have 'measurable' qualities, but their punitive and/or therapeutic effect is determined at least in part by their subjective experience, or in other words, how specific individuals experience them: in relation to their own personal characteristics, past experiences and the perceptions of punishment and the role of the institution in enforcing it. Although issues of mental and physical health have been addressed in carceral settings, when specifically juxtaposing carceral spaces and therapeutic landscapes, there are significant issues of extrapolation (Moran and Turner 2018). As Moran and Turner explain, a barrier is raised 'in 
terms of the perceived legitimacy of a 'healing' custodial function' (2018: 1). Notably, other institutions, such has hospitals, holistic therapy centres or drug rehabilitation units have an explicit 'healing' function that encompasses wellbeing, in addition to relief from physical symptoms, illness or trauma. Stress reduction and increased levels of comfort for individuals dealing with emotionally and/or physically demanding experiences are part of their functionality and legitimacy (Cooper-Marcus and Barnes 1995). A therapeutic landscape is, then, one with an 'enduring reputation for achieving physical, mental and spiritual healing' (Gesler 1993: 171). The parallels with prison space may not be immediately obvious. In the above-mentioned examples there is no overt intent to 'punish' inhabitants, usually viewed as needing and deserving assistance ${ }^{4}$. Conversely, there is little perceived public sympathy for prisoners. With a vigilant(e) media critiquing 'undeserved' 'perks' for prisoners, combined with tight budgets and hyper-attention to security, the penal landscape is rarely 'therapeutic' either in intent or in actual lived experience.

Although emergent research recognises the benefits of therapeutic 'green spaces' in custodial settings (Jewkes and Moran 2014; Wright 2017; Moran and Turner 2018), it is yet to consider 'blue spaces' in a similar manner - perhaps because the relationship between water and carceral space is problematic. The location of a prison near to water is, as far as we can deduce, rarely if ever intended to deliver therapeutic effects. Rather, its proximity necessitates, or is the after-effect of the need for, as an example, prisoner labour when, in the nineteenth century, prisoners built harbours such as at Peterhead in northern Scotland; or water is used as a barrier to escape, as in the island prisons at Alcatraz, at Bastøy in Norway's famous 'eco-prison' located approximately four kilometres from the Norwegian mainland, and at Suomenlinna, a ferry ride from the Finnish capital Helsinki. Proximity can also be the result of sheer coincidence or 
expediency (if the state already owns land in a coastal or waterfront area, thus avoiding the need to purchase an alternative plot elsewhere). Additionally, even where water appears to be part of a progressive regime aimed at improving prospects of rehabilitation, it can have unintended consequences. For example, Bast $\varnothing y$ might seem like an idyll where prisoners can fish from the banks, swim in the water and earn a certificate in maritime proficiency by operating the daily ferry. But the island's water-boundness reinforces many of the negative cultural associations of prison islands, and the bittersweet juxtaposition of (relative) 'freedom' and restriction of liberty brings its own insidious 'pains' (Hancock and Jewkes 2011) to the extent that some prisoners simply cannot cope and request a transfer to harsher but more conventional prison conditions on the mainland (Shammas 2014).

Beyond this, as Turner and Moran (2018) explain, the presence of water in the carceral setting is part of an infrastructure of 'careful control'. In particular, 'water may be considered to be an element requiring restriction because it poses some kind of risk, that is, a risk of an individual flooding their immediate environment or the risk of an individual causing bodily harm to themselves or others' (Turner and Moran 2018: 2). This mechanism of control has broadly negative connotations, including the control of behaviour and spatial activities as in the case of water cannons for crowd control or water torture as an interrogation technique (Arntzen and Werner 1999; Rejali 2009). Similarly, water is also 'controlled for the management of prisoner health, such as for cleansing and anti-contagion mechanism' (Turner and Moran 2018: 2). There are numerous historical examples of the forced bathing of prisoners as part of the reception process (One-Who-Has-Endured-It 1877). Indeed, relics of this infrastructure - e.g., communal baths and 'assembly-line' showers - have become a key part of the narrative at penal tourist sites such as Alcatraz. The significance of water and ablutions, has featured heavily in the rhetoric for 
creating humane prison environments, particularly in relation to the focus of the development of the infrastructure of the prison cell. In-cell sanitation poses the risk of an individual flooding their cell or causing bodily harm to themselves or others, a risk averted by providing showers rather than baths, and restricting the flow of taps and showerheads. Guidelines drawn up by the International Committee of the Red Cross (ICRC) in 2012 and the United Nations Office for Project Services (UNOPS) in 2016 are intended to ensure adequate standards are met. From suggestions about the volume of water required per prisoner per day, to the litre-per-minute flow and number of taps that should be provided, water has become a quantifiable resource for the maintenance of health and wellbeing. The ICRC also recognises variances in geographical locations and cultural contexts. Although still employed elsewhere (including in Ireland), England and Wales abolished the practice of 'slopping-out' (where, lacking in-cell sanitation, prisoners had to urinate and defecate in pots emptied in the morning) in 1996. As recently as 2012, ten British prisons were still believed to be using the practice but, following several legal cases brought by prisoners, in-cell sanitation is the norm for new-build prisons in the UK, and although 'en-suite' cells have received media criticism, such provision is now recognised as essential. Nevertheless, whatever positive prison function may be ascribed to water, it is framed in the language of necessity and minimum standards, or decency, rather than in relation to the notions of leisure and therapy that infuse academic literatures on healthy blue space.

Such therapeutic literature frequently focuses on the necessity of bodily immersion for therapeutic effect, arguing that benefits of seascape generally accrue to individuals viewing a blue space they can also access physically. The sight of blue space bolsters bodily experiences of the seashore, and memories of aquatic activities (Peters and Brown 2017; Steinberg and Peters 2015). Indeed, Wylie's (2005) exploration of the self and landscape on a coastal path critically 
interrogated the significance of walking by the sea and movement in relation to the sea and the shore. Yet, visual interaction with landscape alone does reduce stress for prisoners, even if they are unable to physically access it. In 1981, Moore found that prisoners who were only able to view the prison courtyard from their cells were 24 per cent more likely to make sick-call visits than prisoners who had a view of surrounding farmland. More recently, Moran (2019) has shown that both access to green spaces and views of large images of nature produce therapeutic effects amongst prisoners. Taking a lead from Moore (1981) and Moran (2019), we interrogate the significance of a sea view from a prison cell in the context of therapeutic landscape, health and wellbeing.

\section{Data generation}

Fieldwork was carried out at the case study prison in the summer of 2015 as part of a major ESRC-funded project investigating how penal aims and philosophies (what prison is 'for') are expressed in prison architecture and design; and the effectiveness of prison architecture and design for conveying and delivering that penal purpose. The UK institution we discuss here houses adult male offenders and both adult and young offender females. Multi-method data collection comprised ethnographic observations, an anonymous prisoner survey $(\mathrm{n}=85,22.6$ per cent overall response rate, with 42.5 per cent for females although they represented only 10.6 per cent of the total surveyed population), and focus groups and interviews with staff and prisoners. Data were analysed using SPSS and NVivo. Observations were carried out in individual prison cells, wings, special care units, healthcentre, visiting suite, education spaces and workshops. 29 focus groups (2-6 prisoners) were conducted (in prison wing spaces but not in cells), and 42 prisoners and 36 staff participated in one-to-one interviews. For procedural reasons, prisoner 
interviews took place in interview rooms, i.e. away from cells themselves. Although interview questions were not specifically directed towards a 'sea view' - as many cells did not have such a view - blue space proved particularly relevant to discussions surrounding views in general, as well as the notion of colour in the prison landscape.

\section{'Escape' on the horizon}

Is blue space meaningful in the prison environment? A prison cell with a sea view came as something of a surprise to our prisoner respondents. Although 75 per cent had been in custody before, (an average of eight previous sentences), the fact that the prison was newly-built meant that around half of our interviewees had never been incarcerated there before, so its proximity to the sea was unexpected, and was frequently used as a point of comparison to other prisons. Tony's exuberant language clearly expresses his surprise:

See when you were upstairs [on the upper levels of the accommodation building] you can just see the water and all the boats and that ... Seeing like folk on speedboats like racing and that. Holy shit! It's alright, like.

Prisoners were keen to draw such comparisons. In this example from a focus group with male prisoners, participants' language emphatically demonstrated how unusual they found the view of marine life:

Interviewer: Does the view out of the window make a difference? 
Harry: Oh big difference, please believe it. I've been in a while and I'm used to seeing just concrete walls round us or a fence round us.

Damien: People like you, you lifers [referring to another member of the group], you could do with a better view couldn't you, to be honest?

Harry: Oh definitely...

Damien: Like people like us who are doing fours, fives [years], it's not really a big difference ...

Harry: I've been in nine [years] just now. And as you don't get out this is the first I've ever seen a view like this. ...But this is fucking crazy!

Terry: See the town, the harbour, the boats ...

Harry: ...it's great. I've seen the dolphins, I've seen the whales out at sea.

Terry: It does make a difference doesn't it? It makes it a bit better [you know].

Harry: Oh a big difference.

Sean: There's not many jails you can see that, you've seen dolphins, whales from your cell window.

Harry: It's brilliant man, know what I mean. I stand looking out watching dolphins.

Sean: It was last week we were watching the dolphins. Last week we were watching the dolphins!

Although this was not discussed explicitly at the focus group, it could be that in contrast to the apocryphal tale of Bruce the Alcatraz shark circling in search of escapees, the sight of these wild cetaceans out in the ocean on their migratory routes, as well as being a source of amazement and entertainment, was also a poignant sight for their captive viewers. 
The experience of this view must be considered in relation to respondents' exposure to it or, in other words, the proportion of their time that was spent in cells and on adjacent landings where such views were available. At the case study prison, regime varied slightly between wings and for prisoners undertaking different forms of work, etc. but, in general, prisoners would be away from their cells and landings for about five hours each day. During the remaining 19 hours, they would be either confined to their own cell (i.e. overnight) or to the space comprising their landing and the unlocked cells - i.e. able to look at the view from their own cell window, from the landing windows, and potentially from the windows of other prisoners' cells. This means that, if their own cell had a view of the sea, they would be able to look at this view for the majority of the day - including at night when illuminated by the moon, harbour lights, shipping vessels and oilrigs.

Given this extensive exposure, it is heartening that as well as recounting particularly notable occasions (as in the focus group above), most participants indicated positive associations with the sea view, using words descriptive of a therapeutic effect, including feelings of comfort, ease, relaxation, stress-reduction, restfulness and peace; as well as fascination, exhilaration, distraction and excitement. Beyond this, it may be argued that the experience of the sea view from the more private, individual space of a prisoner's cell increased the likelihood of them being able to convert experience of that sea view to these positive emotional and affective responses. Indeed, many prisoners commented on the way the view enabled the passing of time or 'escape' from the monotony of prison life. As Mikey explains: 
A view's a good thing. It makes your time go by. I notice myself just sitting watching stuff outside and an hour or two's gone by. Whereas if you're just looking at your wall downstairs, even just looking out at the main walls, it does your nut in, that.

Additionally, as Jimmy intimates, the therapeutic effects are derived distinctly from the distraction of and association with the sea:

...if I came in at the start of my sentence and having that view it would help me not think of depression and despair and things like that because you're seeing outside. Especially on a stormy night with the sea and things like that.

Prisoners explained that being able to see the sea enhanced their ability to sleep (or that if they were able to move to a cell with a window that overlooked such a view it would provide that benefit). Others reflected on the feelings of relaxation and peace derived from the ability to visually interact with the weather or sunsets, augmented by the elemental characteristics of the water (such as the smells and sounds of the sea. As Scott explained:

I love looking at the sea. I never used to like the sea, it was until I went out there and you see some of the sunsets it is just gorgeous like and even with the thunder and lightning, I liked that as well, but everyone has different... I think when you start getting older you're not young and dumb anymore. I love the sea it's so peaceful like, it's the best thing you can do with the sea, like the fishing boats sailing along the side of us. 
These engagements with the landscape hint at the importance of awareness of the passage of time. A wealth of scholarship makes clear the disorientation caused by timelessness in prison, and the sense of repetition and being 'left behind' that it causes (e.g. Moran 2012, Kotova 2018). One benefit of nature views is their propensity, in seasonal climates, to enable those who view them to maintain contact with the seasons and thereby the passage of time. In commenting on the apparent progression of the sun, and the corresponding patterns of fishing boat trips, Scott gives us another example of the ways in which blue views enable temporal awareness. A firm criterion of a therapeutic environment is the ability to allow the individual to 'escape' from the circumstances that are causing them harm, allowing them to metaphorically cross the boundary between the prison and 'freedom' (Turner 2016). In the prison environment, legitimate escape i.e. which allows an individual to feel removed from the mental or bodily 'pains of imprisonment' (Sykes 1958) without compromising their physical security within carceral space - may be facilitated by a sea view. As prisoners Damien and Stephen recounted:

Damien: I can spend ages looking out the window and drifting away...it's made my time a lot better. Especially for long term prisoners, people that have got a large majority of their life stuck in here, little things like that that don't cost anything do make a difference. It helps the time become a bit more bearable, to be honest.

Interviewer: What's good about looking at the [sea and harbour area]? How does it make you feel to do that?

Stephen: Sort of tranquil. You can gather your thoughts and just think about what you're going to do when you get outside again. It's good to see some civilisation. 
Staff members also talked of prisoners and officers 'just daydreaming' while standing at the floor-to-ceiling windows in each living unit, which were likened in one case to 'infinity swimming pools', such was the way the sea view appeared at the end of the corridor (prison officer). However, a sea view is not enjoyed in every area of the prison. Scott explained that unless you are located in the upper storeys of the house block, your cell window looks out only onto the exterior perimeter or internal spaces such as the exercise yard or sports pitch:

Interviewer: What view have you got on the ground floor?

Scott: The fence, you can't really see much because it's closed off, but I've been upstairs and it's a beautiful view if you're [...] on the left hand side because you've got the harbour, you've got the ships coming in. A lot of people will sit there and just watch the ships coming in and going out. I'm not really too interested in seeing ships moving back and forth or watching people picking up their crab boxes. You see the orange box placed wherever. But I can see where they get the interest from.

Although prisoners' enjoyment of the seascape is arguably a personal preference, this view was coveted by the majority of our prisoner participants. Accordingly, cells without such a view harness fewer positive associations - the outside space is an agent of change upon the inside space of the cell. Reflecting on the limited vistas offered by ground floor rooms, Ali offered suggestions to improve these views, to ensure prisoners were given an equal outlook: 
You can't see past the wall. To me, you could have... say if you're in the Blackpool Tower, I don't know if you've ever been in the Blackpool Tower, you can walk along one part of the section. There's like the four corners, and then one piece of pure glass ...And I'm thinking why can't you have a big section of that wall that's glass in that sense? But then again, if that's like the sea, that could be the seaside. Or maybe not the sea, you could maybe look through there to that part, and maybe see a boat. It'd be like a picture. [I'd be] coming alive, looking at it.

There is undoubtedly recognition that this kind of interaction with the sea is different to those experiences discussed in the healthy blue space literature. Prisoners are not able to enjoy physical immersion and therefore opportunities to enjoy other embodied, elemental entanglements are extremely valuable. A prison officer working in the residential unit explained:

[C]ertain cells are quite popular ... you'd get the ones in the top flat requesting the ones that were facing the sea because they'd have the breeze coming in from the sea, plus the view out ... So a view is quite important to a lot of cons [convicts - prisoners].

More than simply contributing to the maintenance of health and wellbeing, many participants believed the views from their cell windows could have a rehabilitative effect. Being able to see the outside world was something that Benjamin felt was crucial to reduce the 'shock' of release from prison after a lengthy sentence: 
A person that's getting close to their release, maybe they've been in for a long time, it's going to be quite daunting for somebody just to walk straight into the garden, things have changed outside that you can't see past the walls. So stuff like that you can see outside, see the countryside and that, at least you can see changes. Somebody could be in prison for 10, 20 years, there's a lot of massive changes.

Jimmy described the enjoyment that he felt when he was able to visit another prisoner's cell, which had a sea view. Reflecting on his own experiences as a long-term prisoner coming to the end of his sentence, he explained that a cell with a similar view would likely be more beneficial to a person entering the prison, at the beginning of a long sentence:

If I knew I was going to be here for over a year I'd have took the opportunity for one of the cells that had a sea view because I've sat in one of my pal's cells and you see the boats and that coming in. And I haven't seen the sea since 1994, so when I seen the sea and seen boats coming in. Well, one guy said "look at the smirk on his face". You know? It was just... my eyes were just taking it in. It was nice ... I can move just now if I wish it. But the same again, I'm going to be here for hopefully just a year, so I'd rather somebody else gets that cell if they're doing a big, big sentence because it would be better for them.

We explore the ways in which prisoner culture and the relative 'values' placed on cells with different views by different prisoners elsewhere (Jewkes et al. 2019). Here, we consider the cell space in conjunction with the sea view, performing itself as a liminal carceral space (Moran 2013) of transformation and mobility, which is inherently contra the traditional view of the 
prison cell as the most static, replicated or 'constant' space within the prison. However, while the benefits of a sea view for health and wellbeing was clearly expressed by many participants, such opinions were not universal. In the following section, we explore how for some prisoners, the sea view could be viewed as negative, even detrimental.

\section{A view too far?}

The relational nature of cell space means that its experience is akin to a transaction between its observable qualities (such as the presence or otherwise of a sea view) and the subjectivity of the occupant (such as whether or not they personally find a view of the sea relaxing). In our study, some responses indicated that the waterscape was far from therapeutic and some prisoners emphasised that the sea view - no matter how temporarily interesting or momentarily beneficial - may eventually form part of the monotony of a prison sentence (as is often the case with other aquatic landscapes that become unnoticed after a period of time; Steinberg and Peters [2015]). For example, Duane characterised the seemingly always mobile landscape of a working port in terms of stasis. Here, he makes a critical link between the present blue space and his memories of life prior to prison:

I can see the compensators for the gates at the harbour...But now and again looking out our window does your head in. Because I can see our compensators and the cranes so that reminds me of the oil rigs. So then it puts my head back to where I've come from and where I am now.

In this respect, blue space may reinforce the loss of liberty and autonomy. Despite its positive 
connotations for individuals outside of prison, the coastline is a barrier and obstacle to physical escape. A seemingly-endless horizon reinforces the closed space of the prison cell from which it is viewed. Much like the 'shark-infested' waters around Alcatraz Island, the seascape becomes imbued with messages of stasis and helplessness, creating a juxtaposition between past life and current life in the prison cell.

The ability of blue space to act as a memorial landscape, as it does for Duane, is similarly frustrating for other prisoners. When talking about the proximity of the sea, Melody was initially positive, but was adamant that it would have detrimental effects over the longer term. From her cell, she was only able to see the perimeter wall, internal fences and a small portion of the garden area designated for use by female prisoners. She recalled an occasion where she visited another prisoner's cell:

...I went upstairs last week to speak to a friend of mine, [name] who got out yesterday, and what a view you had from her room. You can actually see the whole harbour and see some of the town. It was pretty, it was nice, but I wouldn't like to look at that all the time, I think it would drive me nuts. Because you can see daily life going on out there. I prefer the regime, I think. ... It's nice to look at, but I would just want to be out there all the time. It would drive me crazy.

Melody went on to recall her feelings when a local festival was held in the adjacent town. As well as events on land, power-boats and acrobatic planes circled the harbour. Although she did not have a direct view, the sounds of the water sports carried into the prison. She explained: 
Last week they had some boat ride or something, some fair, and it was like next to the window. And that was at eight o'clock, and as soon as I opened the window and looked out, all my heart was melting away, I just felt like my heart was racing, I had to pull the blind down. It was just too much. I had to lie there. It was like I shot [sic] it down, just pulled down the curtain...

For Melody, the cell's permeability rendered its ordinary purpose as a private, sanctuary space impossible. These sentiments take us back to San Francisco and the well-known (perhaps apocryphal) story that the least popular cell in Alcatraz was the one at the end of the facility from which holiday-makers could be seen and heard enjoying themselves on the beach across the bay and where, on New Year's Eve, prisoners reported hearing the tinkling of champagne glasses and laughter carried across the water by sea breezes (Jarvis 2004). The sounds of others' enjoyment was simply too painful to bear and only exacerbated inmates' sense of enforced isolation. In addition to the activities associated with blue space, prisoners and staff also commented on several other negative 'effects' of living and working within close proximity to the sea. These ranged from inclement weather to the presence of pestilent seabirds and the unpleasant smells of seaweed and sewage effluent in (particularly urban) coastal areas. These sentiments are contra to the literature that describes the sea as a space of freedom, openness, vitality and lack of restriction (Anderson and Peters 2014; Hastrup and Hastrup 2015). Here, we may draw on work that focuses on the capacity of water/sea to evoke fear, sickness and other less positive notions (Anderson and Peters 2014). In this vein, the physical porosities of the prison architecture create a blurred boundary between sea- and cell-space. 
These types of unwelcome interaction are significant in that they lead us to appreciate that the blue space relationship for incarcerated individuals is at best ambiguous. It is apparent that what at first glance appears to be merely a visual interaction with blue space is in fact manifest in wider embodied interactions. Additionally, it is the lack of agency in relation to blue space that affords opportunities to reconsider how 'healthy blue space' might be interrogated under contingent circumstances. Our research found that, although visual interaction with seascapes can have therapeutic effects and engender feelings of freedom, it may also reinforce insidious aspects of carceral control and loss.

\section{Managing viewpoints}

The absence of a pleasant outlook from certain cells seemed to send a clear message about the treatment that prisoners could expect and about penal philosophy more broadly. As Kyle pondered:

I think it helps, not the bars on the window but what you can see outside the window. ...Because some jails you go to all you can see is a wall and that's not helping at all. It reminds you you're in a cage within another cage.

So, in relation to this, as part of an architectural design strategy that may serve to send a rehabilitative message to incarcerated individuals, the following question may be asked: could a seascape aid rehabilitation? Both staff members and prisoners agreed that top floor cells with a sea view could be used to incentivise prisoners. In a performance of disciplinary power, good behaviour could be rewarded with allocation of these cells, which were described as having the 
best atmosphere, outlook and 'ambiance' (interview with security staff member). In relation to the seascape at our case study prison, one support staff member suggested that it was simply 'bizarre' that the whole prison wasn't facing the water as he '[couldn't] see any negative aspect of prisoners ... looking at the sea' (interview with non-custodial staff member). However, the relatively limited number of cells with coastal views was clearly intrinsic to the, arguably tension-filled, behavioural compliance model operated in this prison, where prisoners could be incentivised to exhibit good behaviour through offers to move to cells with a sea view, or be down-graded to units without such a view if they failed to comply. In this final excerpt, a prison officer highlights this element of 'choice':

As yourself, you go on holiday, if you get a choice, say you go away to Spain or wherever, and they say to you in the hotel "what would you like to face?" ...You'd pick the sea, of course you would. Every time. So I think prisoners are like that.

It is this assumption - that a purposeful location of carceral space within healthy landscapes, in particular, blue space, may be beneficial to those working and living there - that we take forward in our concluding comments.

\section{Conclusion}

Prior discussion of sea views tends to highlight the benefits for individuals located close to blue spaces they can also access physically, with visual experience complementing therapeutic immersion. In this particular prison environment, although prisoners have limited interaction with the blue landscape from their cells, it is nevertheless enables 'escapes' and freedoms for 
some, whilst this has a counter-therapeutic effect for others that often results in a complicated relationship with the space of the prison cell - the space in which prisoners spend the majority of their time. As such, we may question whether Foley and Kistemann's (2015) notion of healthy blue space can be wholeheartedly adopted. In concluding this chapter, we call for the expansion of inquiry into therapeutic landscapes to the notion of the healthy blue space under contingent circumstances, e.g. in conditions of incarceration where individuals cannot choose whether to accept or reject interaction with these cell landscapes and/or where access to such landscapes may be part and parcel of a system of behavioural control. With this in mind, we would welcome the expansion of healthy or therapeutic landscapes into other arenas of study that may exhibit conditions of lack of agency and enforced geographical location, e.g. hospitals, care homes, hospices or social housing; and in particular where waterscapes do not necessarily meet the conventional definitions of therapeutic, such as industrial coastlines or landscapes with particular dangers, such as coastal erosion or water pollution.

Additionally, while recognising that a sea view from a prison cell is not necessarily a priority for a successful prison, we are confident that proximity to and views of blue spaces may be managed in order to maximise their potential positive impacts on health and wellbeing. In a recently-designed prison in Denmark, architects developed a staggered, 'saw-tooth' design to ensure that each cell window has a view of the surrounding countryside and does not overlook any of the prison buildings, thus forcing an exterior view away from the prison itself, towards the 'outside' world. In a similar way, blue landscapes may be incorporated into the design of a prison, such as the lake that forms a central feature of The State Prison of East Jutland at Enner Mark, Denmark, which opened in 2006. In taking a lead from such examples, we believe that intentional use of blue space in a custodial setting could serve to reinforce the values of the 
justice system inasmuch as it facilitates health and wellbeing among prisoners, which form a core component of the wider aims of rehabilitation and reduction of recidivism among offenders.

\section{References}

Airey, L. (2003). 'Nae as nice a scheme as it used to be': lay accounts of neighbourhood incivilities and well-being. Health \& Place, 9(2), 129-237.

Anderson, J. \& Peters, K. (Eds.) (2014). Water Worlds: Human Geographies of the Ocean. Farnham: Ashgate.

Arntzen, E. \& Werner, S.B. (1999). Water mist punishment for two classes of problem behaviour. Scandinavian Journal of Behaviour Therapy, 28(2), 88-93.

Babyak, J. (2001). Breaking the Rock: The Great Escape from Alcatraz. Oakland, CA: Ariel Vamp Press.

Casey, E.S. (2001). Between geography and philosophy: what does it mean to be in the placeworld? Annals of the Association of American. Geographers, 91(4), 683-693.

Cooper-Marcus, C. \& Barnes, M. (1995). Gardens in Healthcare Facilities: Uses, Therapeutic Benefits and Design Recommendations. Concord, CA: The Center for Health Design.

Conradson, D. (2005). Landscape, care and the relational self: therapeutic encounters in rural England. Health \& Place, 11(4), 337-348.

Corbin, A. (1994). The Lure of the Sea: The Discovery of the Seaside in the Western World 1750-1840. Cambridge: Polity Press.

Deakin, R. (2000). Waterlog: A Swimmer's Journey Through Britain. London: Vintage.

Depledge, M. \& Bird, W.J. (2009). The Blue Gym: health and wellbeing from our coasts. Marine Pollution Bulletin, 58(7), 947-948. 
Foley, R. (2015). Swimming in Ireland: immersions in therapeutic blue space. Health \& Place, 35, 218-225.

Foley, R. \& Kistemann, T. (2015). Blue space geographies: enabling health in place. Health \& Place, 35, 157-165.

Gesler, W.M. (1992). Therapeutic landscapes: medical issues in light of the new cultural geography. Social Science \& Medicine, 34(7), 735-746.

Gesler, W.M. (1993). Therapeutic landscapes: theory and a case study of Epidauros, Greece. Environment and Planning D: Society and Space, 11(2), 171-189.

Gesler, W.M. (1996). Lourdes: healing in a place of pilgrimage. Health \& Place, 2(2), 95-105.

Gesler, W.M. (1998). Bath's reputation as a healing place. In R.A. Kearns \& W.M. Gesler (Eds.) Putting Health Into Place: Landscape, Identity and Well-Being (pp. 17-35). Syracuse, NY: Syracuse University Press.

Hancock, P. \& Jewkes, Y. (2011). Architectures of incarceration: The spatial pains of imprisonment. Punishment \& Society, 13(5), 611-629.

Hastrup, K. \& Hastrup, F. (Eds.) (2015). Waterworlds: Anthropology in Fluid Environments. Oxford: Berghahn Books.

Heidegger, M. (1962 [1927]). Being and Time. Trans. John Macquarrie and Edward Robinson. New York: Harper.

Her Majesty’s Inspectorate of Prisons. (2014). Expectations: inspection criteria. https://www.justiceinspectorates.gov.uk/hmiprisons/about-our-inspections/inspectioncriteria/. Accessed 26 August 2018.

International Committee of the Red Cross (ICRC). (2012). Water, Sanitation, Hygiene and Habitat in Prisons. Geneva: International Committee of the Red Cross. 
Jarvis, B. (2004). Cruel and Unusual: Punishment and US Culture. London: Pluto Press.

Jewkes, Y. \& Moran, D. (2015). The paradox of the 'green' prison: Sustaining the environment or sustaining the penal complex? Theoretical Criminology, 19(4), 451-469.

Jewkes, Y., Moran, D. \& Turner, J. (2019). Just add water: prisons, therapeutic landscapes and healthy blue space. Criminology \& Criminal Justice. doi: 10.1177/1748895819828800.

Jordan, M. (2011). The prison setting as a place of enforced residence, its mental health effects, and the mental healthcare implications. Health \& Place, 17(5), 1061-1066.

Kearns, R.A. \& Barnett, J.R. (1999). Auckland's Starship Enterprise: placing metaphor in a children's hospital. In A. Williams (Ed.) Therapeutic landscapes: The Dynamic Between Place and Wellness (pp. 169-200). Lanham, MD: Rowman and Littlefield.

Kearns, R.A. \& Gesler, W.M. (Eds.) (1998). Putting Health Into Place: Landscape, Identity and Well-Being. Syracuse, NY: Syracuse University Press.

Kotova, A. (2018). 'Time... lost time': exploring how partners of long-term prisoners experience the temporal pains of imprisonment. Time \& Society. doi: 10.1177/0961463X18763688.

Lange, E. \& Schaeffer, P.V. (2001). A comment on the market value of a room with a view. Landscape and Urban Planning, 55(2), 113-120.

Lengen, C. (2015). The effects of colours, shapes and boundaries of landscapes on perception, emotion and mentalising processes promoting health and well-being. Health \& Place, 35, 166-177.

Luttik, J. (2000). The value of trees, water and open space as reflected by house prices in the Netherlands. Landscape Urban Planning, 48(3-4), 161-167.

Moore, E. (1981). A prison environment's effect on health care service demands. Journal of Environmental Systems, 11(1), 17-34. 
Moran, D. (2012). "Doing time” in carceral space: Timespace and carceral geography. Geografiska Annaler: Series B, Human Geography, 94(4), 305-316.

Moran, D. (2013). Between outside and inside? Prison visiting rooms as liminal carceral spaces. GeoJournal, 78(2), 339-351.

Moran, D. \& Turner, J. (2018). Turning over a new leaf: The health-enabling capacities of nature contact in prison. Social Science \& Medicine. doi:10.1016/j.socscimed.2018.05.032.

Moran, D. (2019). Back to nature? Attention Restoration Theory and the restorative effects of indirect and vicarious nature contact in prison. Health \& Place, 57, 35-43.

Natural England. (2009). Coastal access.

http://www.naturalengland.org.uk/ourwork/enjoying/places/coastalaccess/default.aspx. Accessed 6 April 2009.

Oke, T.R. (1981). Canyon geometry and the nocturnal urban heat island: comparison of scale model and field observations. Journal of Climatology, 1(3), 237-254.

One-Who-Has-Endured-It. (1877). Five Years Penal Servitude. London: R Bentley and Sons.

Palka, E. (1999). Accessible wilderness as a therapeutic landscape: experiencing the nature of Denali National Park, Alaska. In A. Williams (Ed.) Therapeutic Landscapes: The Dynamic Between Place and Wellness (pp. 29-51). Lanham, MD: Rowman and Littlefield.

Parr, S. (2011). The Story of Swimming. Stockport: Dewi Lewis.

Peters, K. \& Brown, M. (2017). Writing with the sea: reflecting on in/experienced encounters with ocean space. Cultural Geographies, 24(4), 617-624.

Rejali, D. (2009). Torture and Democracy. Princeton, NJ: Princeton University Press.

Sacks, O. 2010. The Mind's Eye. London: Picador. 
Shammas, V.L. (2014). The pains of freedom: assessing the ambiguity of Scandinavian penal exceptionalism on Norway’s Prison Island. Punishment \& Society, 16(1), 104-123.

Shields, R. (2013). Places on the Margin: Alternative Geographies of Modernity. Abingdon: Routledge.

Steinberg, P. \& Peters, K. (2015). Wet ontologies, fluid spaces: giving depth to volume through oceanic thinking. Environment and Planning D: Society and Space, 33(2), 247-264.

Strang, V. (2004). The Meaning of Water. Oxford: Berg.

Strange, C. \& Kempa, M. (2003). Shades of dark tourism: Alcatraz and Robben Island. Annals of Tourism Research, 30(2), 386-405.

Sykes, G. (1958). The Society of Captives: A Study of a Maximum-Security Prison. Princeton, NJ: Princeton University Press.

Terry, H. (2016). Swim with sharks: fire captain douses doubts as he returns to sport in race near Alcatraz. http://bouldercityreview.com/community/swim-sharks-fire-captain-dousesdoubts-he-returns-sport-race-near-alcatraz. Accessed 1 September 2018.

Turner, J. (2016). The Prison Boundary: Between Society and Carceral Space. London: Palgrave Macmillan.

UNOPS (2016). Technical Guidance on Prison Planning. Copenhagen: United Nations.

Velarde, M.D., Fry, G. \& Tveit, M. (2007). Health effects of viewing landscapes: landscape types in environmental psychology. Urban Forestry \& Urban Greening, 6(4), 199-212.

Völker, S. \& Kistemann,T. (2011). The impact of blue space on human health and well-being: salutogenetic health effects of inland surface waters: a review. International Journal of Hygiene and Environmental Health, 214(6), 449-460. 
Wheeler, B., White, M., Stahl-Timmins, W. \& Depledge, M. (2012). Does living by the coast improve health and wellbeing? Health \& Place, 18(5), 1198-1201.

White, M., Smith, A., Humphreys, K., Pahl, S., Snelling, D. \& Depledge, M. (2010). Blue Space: the importance of water for preference, affect, and restorativeness ratings of natural and built scenes. Journal of Environmental Psychology, 30(4), 482-493.

Williams, A. (Ed.) (1999). Therapeutic Landscapes: The Dynamic Between Place and Wellness. Lanham, MD: Rowman and Littlefield.

Williams, A. (2002). Changing geographies of care: employing the concept of therapeutic landscapes as a framework in examining home space. Social Science \& Medicine, 51(1), $141-154$.

Wright, H. (2017). Outside Time. HMP Coldingley: Placewise Press.

Wylie, J.W. (2005). A single day's walking: narrating self and landscape on the South West Coast Path. Transactions of the Institute of British Geographers, 30(2), 234-247.

\footnotetext{
${ }^{1}$ See Strange and Kempa (2003) for a critical analysis of tourist experiences on Alcatraz Island.

${ }^{2}$ For Foley and Kistemann, 'blue' is used in reference to 'its established associations with oceans, seas, lakes, rivers and other bodies of water' recognising also, 'the myriad shades and forms (grey, brown, dark, oily, muddy, clear) that are recognisable dimensions of water bodies at different scales' (2015: 158).

${ }^{3}$ For a comprehensive review of therapeutic blue space, see Foley and Kistemann (2015), where examples range from interactions with European rivers to Canadian lakes.

${ }^{4}$ Here we consider that although, in some cases, such spaces may be experienced negatively their healing intention usually prevails.
} 